\title{
OBSERVATIONS ON THE SERUM CHOLESTEROL IN ACUTE INFECTIONS AS RECORDED DURING AND AFTER PNEUMONIA ${ }^{1}$
}

\author{
By ALFRED STEINER AND KENNETH B. TURNER \\ (From the Research Service, First Medical Division, Welfare Hospital, 2 Department of Hos- \\ pitals, City of New York, and the Department of Medicine, College of Physicians and \\ Surgeons, Columbia University, and the Presbyterian Hospital, New York City)
}

(Received for publication October 30, 1939)

In a previous report (1) the relative stability of the serum cholesterol level was demonstrated in normal subjects over long periods of time. The cholesterol values were not altered significantly by the feeding of diets high or low in fat or cholesterol, or by the ingestion of potassium iodide. However, the administration of thyroid extract produced a sharp fall in serum cholesterol which was followed by a rise above normal when thyroid feeding was discontinued.

Acute infection is also known to produce a hypocholesterolemia. This was shown a number of years ago by Denis (2) and Kipp (3) and by numerous workers since. The behavior of the serum cholesterol during convalescence has received little attention. Stoesser and McQuarrie (4) and more recently Stoesser (5) reported that a plasma cholesterol determination made in infants or children convalescent from an acute infection was higher than one obtained at the height of the febrile episode. However, there have been no reports in which repeated determinations were made on the same individual during and for a protracted period after the acute infection. Accordingly, the present study was undertaken in an attempt to demonstrate what happens to the serum cholesterol of individuals who develop an acute infection-an infection which was, in these instances, pneumonia.

\section{PLAN OF STUDY}

Observations were made on 19 patients, varying in age between 12 and 52 years, who were admitted to the hospital with a diagnosis of pneumonia. There were 12 males and 7 females of whom 16 were white and 3 were colored. In the sputum studies on the 19 patients the pneumo-

1 This work was aided in part by a grant from the Josiah Macy, Jr., Foundation.

2 Formerly the Research Division for Chronic Diseases. coccus type was identified in 9 , and the hemolytic streptococcus was found in 3 . Five patients were treated with specific serum, 4 with sulfanilamide, and 1 with optochin. An initial serum cholesterol was determined using the method of Bloor, Pelkan and Allen (6) from blood obtained within 48 hours of the patient's entry to the hospital. Serum cholesterol determinations were made twice weekly thereafter while the patients remained in the hospital. After discharge, the patients were seen at weekly, bi-weekly or monthly intervals for periods ranging from 96 to 520 days. The total number of tests performed was 418, averaging 22 for each patient.

Basal metabolism estimations were made at frequent intervals after the fever subsided. In addition to the usual laboratory procedures, serum protein and bromsulphalein dye retention determinations were made on most of the patients.

\section{Serum cholesterol level during febrile period}

During the febrile period of pneumonia there is a hypocholesterolemia. At the lowest point of each individual curve, which was observed usually on the second to sixth day of the disease, the total serum cholesterol ranged between 86 and 206 mgm. per $100 \mathrm{cc}$. (Table I). At this time a reduction in cholesterol ester was apparent in the 6 patients in whom this fraction was determined. In 1 case the lowest value for the total serum cholesterol was not reached until the twenty-second day. The course of this patient was complicated by the development of active rheumatic carditis subsequent to pneumonia due to a hemolytic streptococcus.

\section{Serum cholesterol level during convalescence}

As soon as the fever subsided the serum cholesterol value in each patient rose, and for a variable 
TABLE I

Serum cholesterol values during and after pneumonia

\begin{tabular}{|c|c|c|c|c|c|c|c|c|c|c|c|c|c|c|c|c|c|c|c|}
\hline \multirow{3}{*}{ Name } & \multirow{3}{*}{ Sex } & \multirow{3}{*}{ Age } & \multirow{2}{*}{\multicolumn{2}{|c|}{ Pneumonia }} & \multirow{3}{*}{$\begin{array}{c}\text { Days } \\
\text { of } \\
\text { fever } \\
\text { over } \\
102^{\circ}\end{array}$} & \multirow{3}{*}{ Treatment } & \multirow{3}{*}{$\begin{array}{c}\text { Total } \\
\text { days } \\
\text { ob- } \\
\text { served }\end{array}$} & \multirow{3}{*}{$\begin{array}{c}\text { Num- } \\
\text { ber } \\
\text { of } \\
\text { choles- } \\
\text { terol } \\
\text { determi- } \\
\text { nations }\end{array}$} & \multicolumn{9}{|c|}{ Serum cholesterol } & \multirow{2}{*}{\multicolumn{2}{|c|}{$\begin{array}{c}\text { Elevation } \\
\text { of } \\
\text { serum } \\
\text { cholesterol }\end{array}$}} \\
\hline & & & & & & & & & \multicolumn{3}{|c|}{ Low } & \multicolumn{3}{|c|}{ High } & \multicolumn{3}{|c|}{ "Normal" } & & \\
\hline & & & Type & Location & & & & & Total & Ester & Day & Total & Ester & Day & Total & Ester & Day & $\begin{array}{l}\text { Ex- } \\
\text { tent }\end{array}$ & $\begin{array}{c}\text { Dura- } \\
\text { tion }\end{array}$ \\
\hline 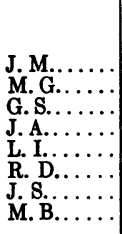 & $\begin{array}{l}\mathbf{F} \\
\mathbf{M} \\
\mathrm{M} \\
\mathrm{M} \\
\mathrm{F} \\
\mathrm{F} \\
\mathrm{M} \\
\mathbf{M}\end{array}$ & $\begin{array}{l}17 \\
25 \\
24 \\
28 \\
38 \\
20 \\
16 \\
12\end{array}$ & $\begin{array}{l}\text { Pneumococcus IV } \\
\text { Pneumococcus IV } \\
\text { Pneumococcus I } \\
\text { Hemolytic }\end{array}$ & $\begin{array}{l}\text { L. L. L. } \\
\text { R. M.L. } \\
\text { L. L. L. } \\
\text { R. L. L. } \\
\text { L. L. L. } \\
\text { L. L. L. } \\
\text { Bronchi } \\
\text { Bronchi }\end{array}$ & $\begin{array}{l}\mathbf{5} \\
\mathbf{9} \\
\mathbf{6} \\
\mathbf{3} \\
\mathbf{4} \\
\mathbf{2} \\
\mathbf{3} \\
\mathbf{5}\end{array}$ & \begin{tabular}{|} 
Sulfanilamide \\
Serum \\
Sulfanilamide
\end{tabular} & $\begin{array}{r}168 \\
210 \\
192 \\
112 \\
120 \\
117 \\
125 \\
96\end{array}$ & $\begin{array}{r}31 \\
31 \\
18 \\
21 \\
23 \\
26 \\
9 \\
17\end{array}$ & $\begin{array}{r}m g m . \\
167 \\
91 \\
140 \\
121 \\
182 \\
101 \\
158 \\
206\end{array}$ & $\begin{array}{c}\text { per } \\
\text { cent }\end{array}$ & $\begin{array}{r}1 \\
10 \\
5 \\
2 \\
4 \\
2 \\
3 \\
4\end{array}$ & $\begin{array}{l}\text { mgm. } \\
312 \\
320 \\
274 \\
297 \\
332 \\
285 \\
293 \\
270\end{array}$ & $\begin{array}{c}\text { per } \\
\text { cent }\end{array}$ & $\begin{array}{l}21 \\
72 \\
39 \\
50 \\
37 \\
25 \\
46 \\
27\end{array}$ & $\begin{array}{l}m g m . \\
210 \\
230 \\
225 \\
210 \\
274 \\
200 \\
185 \\
200\end{array}$ & $\begin{array}{c}\text { per } \\
\text { cent }\end{array}$ & $\begin{array}{r}130 \\
91 \\
60 \\
69 \\
85 \\
87 \\
76 \\
70\end{array}$ & $\begin{array}{c}\text { per } \\
\text { cent } \\
53 \\
39 \\
23 \\
41 \\
25 \\
42 \\
58 \\
35\end{array}$ & $\begin{array}{r}\text { days } \\
40 \\
60 \\
39 \\
50 \\
30 \\
63 \\
60 \\
35\end{array}$ \\
\hline 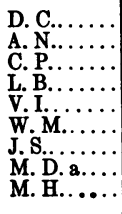 & $\begin{array}{l}\mathbf{F} \\
\mathbf{M} \\
\mathbf{F} \\
\mathbf{M} \\
\mathbf{F} \\
\mathbf{M} \\
\mathbf{M} \\
\mathbf{M} \\
\mathbf{M}\end{array}$ & $\begin{array}{l}15 \\
52 \\
28 \\
17 \\
33 \\
24 \\
34 \\
21 \\
15\end{array}$ & $\begin{array}{l}\text { Pneumococcus II } \\
\text { Pneumococcus IV } \\
\text { Pneumococcus VII } \\
\text { Pneumococcus I } \\
\text { Pneumococcus VII } \\
\text { Hemolytic }\end{array}$ & $\begin{array}{l}\text { R. U. L. } \\
\text { L. L. L. } \\
\text { R. U. L. } \\
\text { L. L. L. } \\
\text { L. L. L. } \\
\text { R. L. L. } \\
\text { R. U. L. } \\
\text { L. U. L. } \\
\text { L. L. L. }\end{array}$ & $\begin{array}{r}4 \\
7 \\
5 \\
5 \\
6 \\
2 \\
5 \\
6 \\
14\end{array}$ & \begin{tabular}{|c|} 
Serum \\
Sulfanilamide \\
Serum \\
Serum \\
Serum
\end{tabular} & $\begin{array}{l}506 \\
187 \\
336 \\
124 \\
119 \\
156 \\
112 \\
330 \\
510\end{array}$ & $\begin{array}{l}42 \\
26 \\
26 \\
16 \\
12 \\
22 \\
20 \\
29 \\
39\end{array}$ & \begin{tabular}{|r|}
123 \\
132 \\
166 \\
157 \\
161 \\
176 \\
86 \\
125 \\
96
\end{tabular} & $\begin{array}{l}48 \\
54 \\
42\end{array}$ & $\begin{array}{r}6 \\
3 \\
5 \\
3 \\
5 \\
4 \\
3 \\
7 \\
22\end{array}$ & \begin{tabular}{l|}
450 \\
344 \\
299 \\
277 \\
263 \\
316 \\
261 \\
358 \\
239
\end{tabular} & $\begin{array}{l}68 \\
86 \\
78\end{array}$ & $\begin{array}{l}76 \\
33 \\
44 \\
31 \\
44 \\
38 \\
30 \\
56 \\
58\end{array}$ & $\begin{array}{l}200 \\
235 \\
210 \\
180 \\
220 \\
266 \\
235 \\
235 \\
200\end{array}$ & $\begin{array}{l}83 \\
70 \\
79\end{array}$ & $\begin{array}{r}170 \\
83 \\
78 \\
47 \\
65 \\
63 \\
90 \\
140 \\
150\end{array}$ & $\begin{array}{r}125 \\
42 \\
42 \\
53 \\
20 \\
20 \\
11 \\
52 \\
20\end{array}$ & $\begin{array}{r}110 \\
61 \\
55 \\
20 \\
31 \\
32 \\
30 \\
57 \\
80\end{array}$ \\
\hline M. D.b.... & $\mathbf{F}$ & 44 & Hemolytic & L. L. L. & 12 & Sulfanilamide & 105 & 12 & 125 & & 4 & 295 & & 10 & 255 & & 85 & 17 & 47 \\
\hline \multirow[t]{2}{*}{ C. R....... } & $\mathbf{M}$ & 52 & Pneumococcus IV & R. U. L. & 7 & Optochin & 520 & 36 & 136 & & 10 & 255 & & 28 & 225 & & 140 & 13 & 92 \\
\hline & & & & & & Average & 217 & 22 & & & & & & 40 & & & 92 & 38 & 52 \\
\hline
\end{tabular}

time during convalescence strikingly wide fluctuations occurred in the cholesterol level (Figure 1). In general, there was a hypercholesterolemia due to an increase in both the ester and free fractions. The serum cholesterol of each of the 19 patients reached a peak during convalescence between the tenth and seventy-sixth days, usually about the fortieth day. The increase in serum cholesterol over the level that was subsequently found to be "normal" for each of the patients varied from 26 to $250 \mathrm{mgm}$. per $100 \mathrm{cc}$., with an average rise of $82 \mathrm{mgm}$. per $100 \mathrm{cc}$. The percentage of increase over the normal value varied from 11 to 125 per cent, with an average rise of 38 per cent. The elevation of the serum cholesterol persisted from 20 to 110 days, with an average of 52 days (Table I). Although the serum cholesterol fluctuated considerably during this period, the general pattern of response was characterized by a rise to a peak, with a subsequent fall toward normal (Figure 1).

\section{Normal serum cholesterol level}

The serum cholesterol reached the level designated as normal from 47 to 170 days after the onset of the illness (Table I). At this point fluctuations in the cholesterol level disappeared and repeated determinations revealed values which were constant for the individual. Previous work by the authors (1) has shown the serum cholesterol to be remarkably constant in normal subjects over long periods of time. The results obtained in this study during the "normal" period which varied from 30 to 380 days, averaging 123 days, confirm this finding. Figure 1 demonstrates this observation in 6 of the patients. In patient D. C. during the 336 days of the normal period the serum cholesterol deviated only $7 \mathrm{mgm}$. from the mean. In patient $C$. $P$. the serum cholesterol varied only $8 \mathrm{mgm}$. from the mean during the normal period of 258 days.

\section{DISCUSSION}

From the foregoing it is evident that during pneumonia there is a decrease in the serum cholesterol level. After the infection subsides and the fever disappears there follows characteristically a rise above the level later found to be normal for the individual, with a marked instability of the serum cholesterol values which may persist for weeks or months before the stabilized level assumed to be normal is reached.

The mechanism producing this alteration in serum cholesterol is not clear. Because of the simi- 

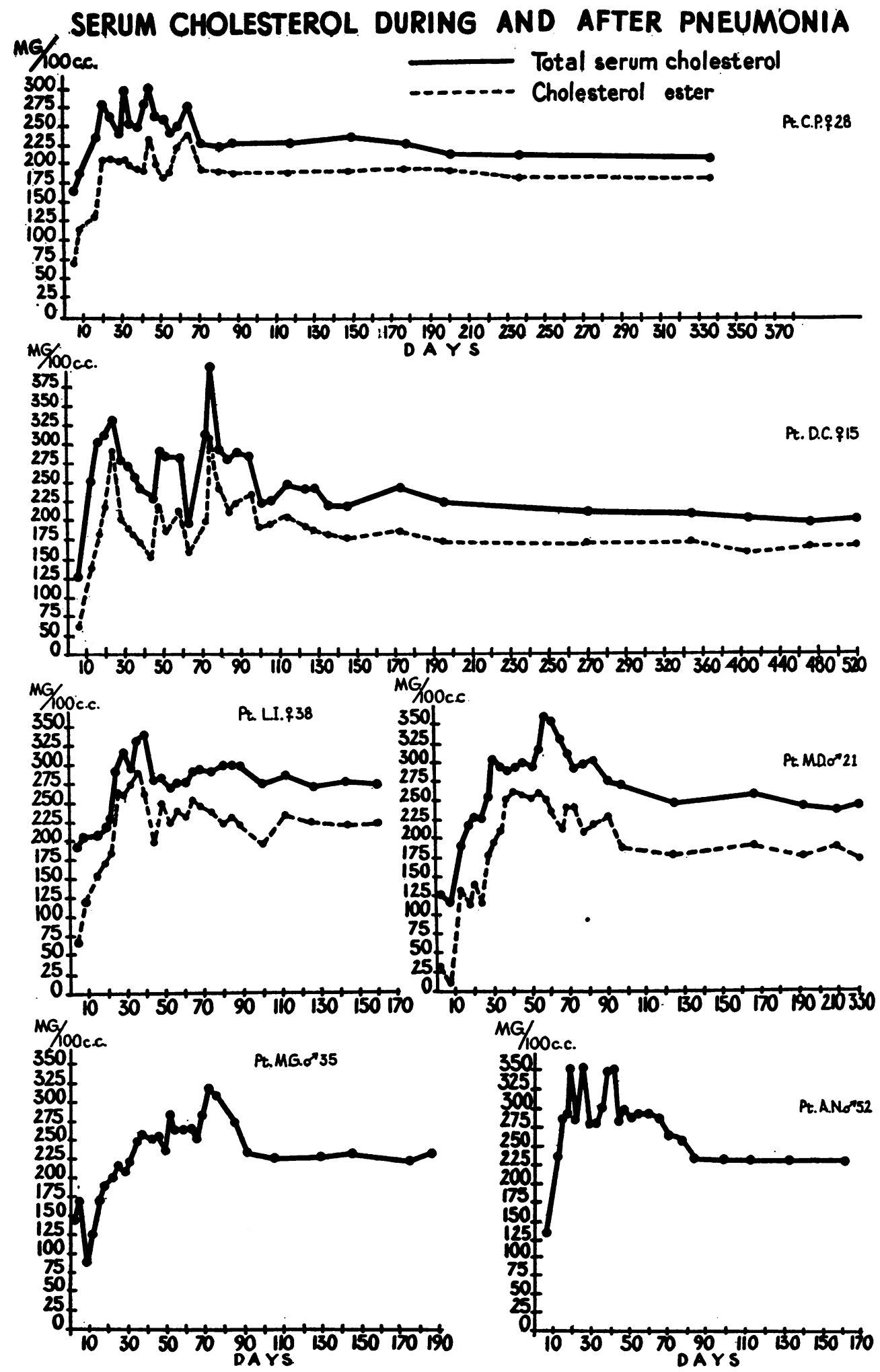

Fig. 1. Illustrative Curves Showing the Depression of the Serum Cholesterol During Pneumonia, the Rise to Abnormally High Levels Associated With Marked Fluctuations During Convalescence, and the Stability Characteristic of Normal WeliBEING 
TABLE II

Relation of basal metabolic rate and serum cholesterol

\begin{tabular}{|c|c|c|}
\hline \multirow[b]{2}{*}{ Patient } & \multicolumn{2}{|c|}{ Basal metabolic rate } \\
\hline & $\begin{array}{c}\text { With } \\
\text { highest } \\
\text { cholesterol }\end{array}$ & $\begin{array}{c}\text { With } \\
\text { normal } \\
\text { cholesterol }\end{array}$ \\
\hline $\begin{array}{l}\text { C. P.. } \\
\text { C. R. } \\
\text { D. C. } \\
\text { L. I.. } \\
\text { M. D. } \\
\text { M. H. }\end{array}$ & $\begin{array}{lr} & \text { per cent } \\
\ldots & -16 \\
\ldots & 0 \\
\ldots & +16 \\
\ldots & +3 \\
\ldots & -16 \\
\ldots & -26\end{array}$ & $\begin{array}{c}\text { per cent } \\
-8 \\
-5 \\
+8 \\
+1 \\
-10 \\
-14\end{array}$ \\
\hline
\end{tabular}

larity of the effect of thyroid administration and of acute infection on the serum cholesterol level and because hypothyroidism may be associated with an elevated serum cholesterol, determinations of the basal metabolic rate were made at frequent intervals after the fever subsided. No constant correlation between the basal metabolic rate and cholesterol level could be demonstrated (Table II). It is of interest, however, that following the lowering effect of thyroid extract administration on the serum cholesterol in humans (1) and in rabbits (7) the serum cholesterol overshot previous values and remained abnormally elevated for several weeks.

The marked fall in the cholesterol ester fraction during the febrile period suggested the possibility of an alteration in hepatic function and it was also considered that the hypercholesterolemia during convalescence might be another expression of the same cause. With this in mind, determinations of the serum protein were made in 10 cases, of which 7 also had bromsulphalein dye retention studies. In 3 instances the observations were made during the febrile period and in the remaining 7 at variable times during convalescence ( $\mathrm{Ta}$ ble III). Only 2 of the 10 patients showed any evidence of depression of liver function.

Therefore, it must be concluded that the mechanism producing these changes in the serum cholesterol level is unknown; nor is the significance of this response of serum cholesterol to infection at all clear. Numerous observers have attached importance to an elevation in serum cholesterol because of its possible rôle in the development of atherosclerosis. The hypercholesterolemia of improperly regulated diabetes mellitus, of myxedema, and of chronic glomerulonephritis has been felt to be a responsible factor for the frequent premature and widespread atherosclerosis associated with these conditions.

It is a common observation that cholesterol deposits (atheromata) in arteries frequently show marked variation and gradation in extent and age. The process of deposition appears to be discontinuous. It is possible that such deposits of cholesterol are related to corresponding periods of hypercholesterolemia. Infection can now be added to the list of conditions resulting in or associated with hypercholesterolemia.

TABLE III

Observations on liver function during and after fever

\begin{tabular}{|c|c|c|c|c|}
\hline \multirow{2}{*}{ Patient } & \multirow{2}{*}{$\begin{array}{l}\text { Interval } \\
\text { fever free }\end{array}$} & \multicolumn{2}{|c|}{ Serum } & \multirow{2}{*}{$\begin{array}{l}\text { Brom- } \\
\text { sulphalein } \\
\text { retention }\end{array}$} \\
\hline & & Albumin & Globulin & \\
\hline 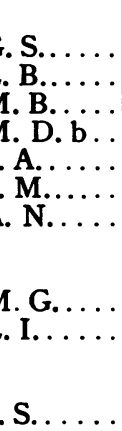 & \begin{tabular}{c}
\multicolumn{2}{c}{ days } \\
(during fever) \\
(during fever) \\
(during fever) \\
3 \\
6 \\
6 \\
8 \\
18 \\
33 \\
10 \\
11 \\
19 \\
26 \\
21
\end{tabular} & $\begin{array}{l}\text { grams } \\
3.4 \\
4.3 \\
4.3 \\
4.0 \\
4.5 \\
4.1 \\
2.9 \\
3.1 \\
3.7 \\
3.9 \\
3.8 \\
3.7 \\
3.9 \\
3.8\end{array}$ & $\begin{array}{l}\text { grams } \\
2.6 \\
2.7 \\
2.7 \\
2.7 \\
2.5 \\
3.7 \\
2.6 \\
3.4 \\
3.1 \\
3.0 \\
3.8 \\
3.9 \\
3.8 \\
2.3\end{array}$ & $\begin{array}{c}\text { per cent } \\
0 \\
0\end{array}$ \\
\hline
\end{tabular}

\section{SUMMARY}

1. The serum cholesterol of 19 patients with pneumonia was followed at frequent intervals for 96 to 520 days after the onset of the disease.

2. Hypocholesterolemia occurred during the febrile stage of the illness and was largely due to a decrease in the ester fraction.

3. Hypercholesterolemia frequently associated with wide fluctuations occurred during convalescence from pneumonia for periods varying from 20 to 110 days, with an average of 52 days.

4. During convalescence the increase in serum cholesterol above that which was subsequently found to be normal for each patient varied from 26 to $250 \mathrm{mgm}$., averaging $82 \mathrm{mgm}$. The percentage of rise above normal averaged 38 per cent for the group of 19 patients.

5. Implication of the thyroid or liver as a factor 
in the alteration of serum cholesterol level subsequent to infection was not demonstrated.

6. Additional evidence confirming the constancy of serum cholesterol in normal individuals was presented.

\section{BIBLIOGRAPHY}

1. Turner, K. B., and Steiner, A., A long term study of the variation of serum cholesterol in man. $J$. Clin. Invest., 1939, 18, 45.

2. Denis, W., Cholesterol in human blood under pathological conditions. J. Biol. Chem., 1917, 29, 93.

3. Kipp, H. A., Variation in the cholesterol content of the serum in pneumonia. J. Biol. Chem., 1920, 44, 215.
4. Stoesser, A. V., and McQuarrie, I., Influence of acute infection and artificial fever on the plasma lipids. Am. J. Dis. Child., 1935, 49, 658.

5. Stoesser, A. V., Altered lipid metabolism in acute infections of infants and older children. Am. J. Dis. Child., 1938, 56, 1215.

6. Bloor, W. R., Pelkan, K. F., and Allen, D. M., Determination of fatty acids (and cholesterol) in small amounts of blood plasma. J. Biol. Chem., 1922, 52, 191.

7. Turner, K. B., Present, C .H., and Bidwell, E. H., The rôle of the thyroid in the regulation of the blood cholesterol of rabbits. J. Exper. Med., 1938, 67, 111. 